Article

\title{
Anti-Cancer Effect of Lambertianic Acid by Inhibiting the AR in LNCaP Cells
}

\author{
Myoung-Sun Lee, Seon-Ok Lee, Sung-Hoon Kim, Eun-Ok Lee and Hyo-Jeong Lee * \\ Department of Cancer Preventive Material Development, Graduate School, Kyung Hee University, \\ 1 Hoegi-dong, Dongdaemun-gu, Seoul 130-701, Korea; lmsms14@naver.com (M.-S.L.); \\ lso4595@naver.com (S.-O.L.); sungkim7@khu.ac.kr (S.-H.K.); leook@khu.ac.kr (E.-O.L.) \\ * Correspondence: strong79@khu.ac.kr; Tel.: +82-02-964-2730; Fax: +82-02-964-1064 \\ Academic Editors: Terrence Piva and Dario Marchetti \\ Received: 8 April 2016; Accepted: 28 June 2016; Published: 7 July 2016
}

\begin{abstract}
Lambertianic acid (LA) is known to have anti-allergic and antibacterial effects. However, the anticancer activities and mechanism of action of LA have not been investigated. Therefore, the anticancer effects and mechanism of LA are investigated in this study. LA decreased not only AR protein levels, but also cellular and secretory levels of PSA. Furthermore, LA inhibited nuclear translocation of the AR induced by mibolerone. LA suppressed cell proliferation by inducing $\mathrm{G}_{1}$ arrest, downregulating CDK4/ 6 and cyclin D1 and activating p53 and its downstream molecules, p21 and $\mathrm{p} 27$. LA induced apoptosis and the expression of related proteins, including cleaved caspase-9 and -3, c-PARP and BAX, and inhibited BCl-2. The role of AR in LA-induced apoptosis was assessed by using siRNA. Collectively, these findings suggest that LA exerts the anticancer effect by inhibiting $\mathrm{AR}$ and is a valuable therapeutic agent in prostate cancer treatment.
\end{abstract}

Keywords: LNCaP; lambertianic acid; androgen receptor; anticancer

\section{Introduction}

Prostate cancer is the second most common form of cancer in males and a direct cause of death in men worldwide [1,2]. The androgen receptor (AR) function is important in sexual and physiological development [3]. In particular, androgen and the AR are important for prostate development [4]. The AR, the role of which was demonstrated in the late 1960s, conducts an important role in the growth and proliferation of androgen-dependent prostate cancer and cells [5-7]. Testosterone and dihydrotestosterone exert their biological effects by binding to the AR and inducing transcriptional activity [6]. AR regulates the prostate-specific antigen (PSA) expression in prostate cancer cells $[8,9]$. PSA is considered the most sensitive biomarker available for confirming the existence of prostatic disease, prostate cancer [10]. Previous studies show that anti-spermatogenesis, anticancer activity and apoptosis in prostate cancer cells were induced by the suppression of AR signaling [11-13]. Furthermore, several studies have reported that p53 regulates the AR, transcription of PSA [14] and induces AR downregulation in prostate cancer [15]. The suppression of anti-apoptosis protein expression by AR-mediated androgen action has been demonstrated as a mechanism for stimulating anti-apoptosis protein expression during androgen deprivation [16]. Lambertianic acid was originally isolated and identified from Pinus koraiensis Siebold and Zucc (Pinaceae) [17]; our previous studies showed that it exerts anti-obesity effects [18]. LA is known to exert hepatoprotective, hemopoiesis-stimulatory and neurotropic activities [19]. However, its anticancer activity has not been investigated. Therefore, the purpose of the present study was to investigate the anticancer activity of LA likely mediated via the AR pathway in LNCaP cells. 


\section{Results}

\subsection{Lambertianic Acid Inhibits Cell Growt}

LNCaP cells were affected more than castration-resistant cells (PC-3 and DU145) by LA (Figure 1B). Incubation with $200 \mu \mathrm{M}$ and $400 \mu \mathrm{M}$ (data not shown) LA for $24 \mathrm{~h}$ reduced LNCaP cell viability by $35 \%$ and $92.2 \%$ (data not shown), respectively, as compared to the control. The growth inhibition was accompanied by $\mathrm{G}_{1}$ phase arrest (Figure $\left.1 \mathrm{C}, \mathrm{D}\right)$. To determine whether LA inhibits cancer cell proliferation following a longer exposure, LNCaP cells were treated with LA $(0,50,100$ and $200 \mu \mathrm{M})$ for three and five days, and then, cell proliferation was examined using crystal violet staining. As shown in Figure 1E, LA decreased the number of LNCaP cells concentration and time dependently (IC $50109 \mu \mathrm{M})$. To determine whether LA affects the expression level of cell proliferation-related proteins, proteins were analyzed using Western blotting. LA treatment for $24 \mathrm{~h}$ decreased the $\mathrm{G}_{1}$ regulat,dicate that the suppression of cell proliferation by LA was mediated by changes in related protein levels.
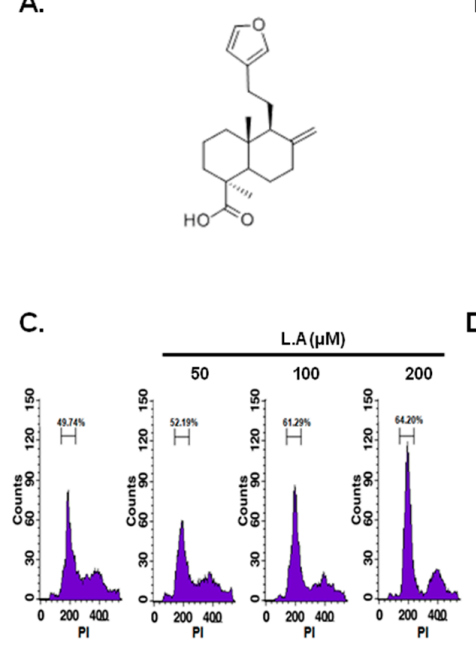

E.

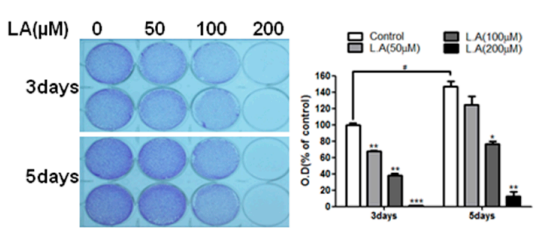

B.

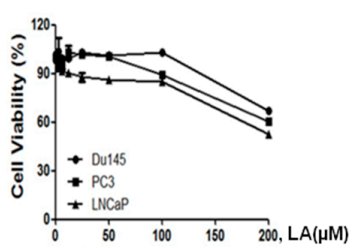

D.

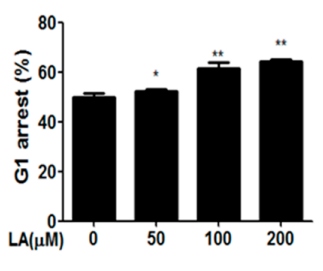

F.

$A(\mu M) \quad 0 \quad 50 \quad 100 \quad 200$

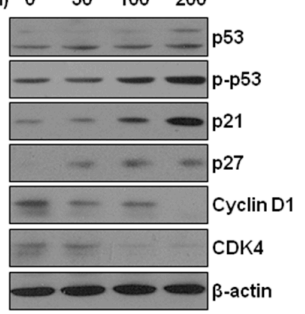

Figure 1. Effect of LA on induced $\mathrm{G}_{1}$ arrest and proliferation after $24 \mathrm{~h}$ of incubation with LNCaP cells. (A) Chemical structure of LA; (B) Cytotoxicity of LA against prostate cancer cells was determined by the MTT assay. Cells were treated with various concentrations of LA $(0,3.125,6.25,12.5,25,50,100$ and $200 \mu \mathrm{M})$ for $24 \mathrm{~h}$; (C) LNCaP cells were treated with LA $(0,50,100$ and $200 \mu \mathrm{M})$ for $24 \mathrm{~h}$ and stained with propidium iodide (PI) after fixation. Stained cells were analyzed using a FACS Vantage flow cytometry system; (D) $\mathrm{G}_{1}$ arrest (\%) in LA-treated cell after $24 \mathrm{~h}$. ${ }^{*} p<0.05$ and ${ }^{* *} p<0.01$ (in comparison to the control); (E) Anti-proliferative activity of LA was evaluated using the cell growth assay. LNCaP cells were treated with LA $(0,50,100,200 \mu \mathrm{M})$ and incubated for three and five days. Cells were stained; then, randomly chosen fields were photographed and resolved in $70 \%$ ethanol after washing with distilled water, and absorbance was read using a microplate reader. $\# p<0.05,{ }^{*} p<0.05,{ }^{* *} p<0.01$ and ${ }^{* * *} p<0.001$ (in comparison to the control); (F) LNCaP cells were treated with LA $(0,50,100$ and $200 \mu \mathrm{M}$ ) for $24 \mathrm{~h}$ and subjected to Western blot analysis of protein levels (p-P53, P53, P21, P27, cyclin D1 and CDK4). 


\subsection{Lambertianic Acid Induces the Apoptosis of LNCaP Cells}

As shown in Figure 2A,B, LA treatment for $48 \mathrm{~h}$ induced the sub- $\mathrm{G}_{1}$ phase for the concentrations of LNCaP cells. To determine the potential molecular mediators of the apoptotic effects, the caspase cleavage patterns, PARP cleavage, Bcl-2 and BAX protein levels were analyzed. LA enhanced cleaved caspase-3 activity (Figure 2C). LA increased cleaved caspase-3 and caspase-9 levels at a $200-\mu \mathrm{M}$ concentration, which corresponded to the increase in PARP cleavage (Figure 2D). Furthermore, LA induced the mitochondrial death mediator protein, BAX, and inhibited Bcl-2.

A.

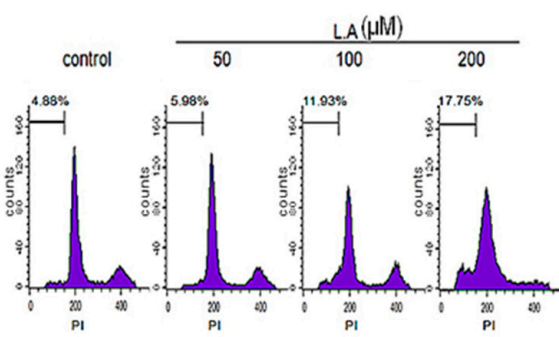

B.

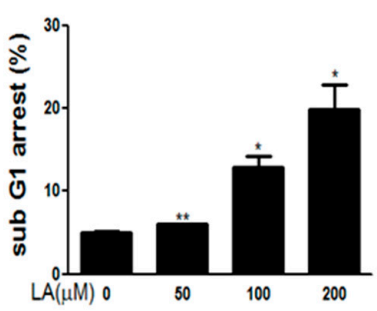

C.

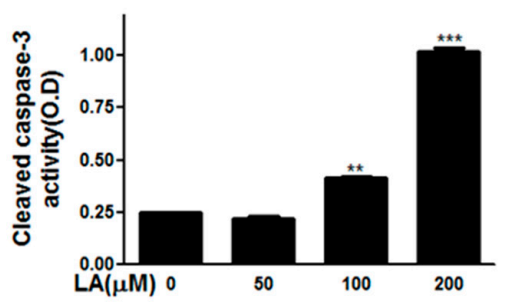

D.

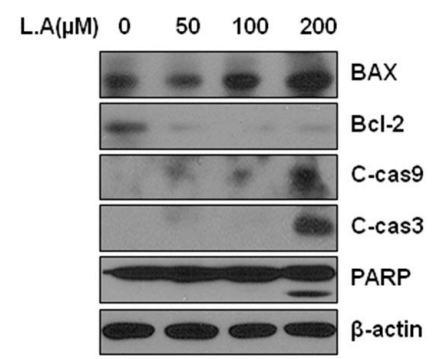

Figure 2. Effect of LA on induced apoptosis after $48 \mathrm{~h}$ of incubation with LNCaP cells. (A) LNCaP cells were treated with LA $(0,50,100$ and $200 \mu \mathrm{M})$ for $48 \mathrm{~h}$ and then stained with propidium iodide (PI) after fixation. Stained cells were analyzed using a FACS Vantage flow cytometry system. Analysis of the cell cycle showed increased sub- $\mathrm{G}_{1}$; (B) Sub-G $\mathrm{G}_{1}$ arrest (\%) in LA-treated cells after $48 \mathrm{~h}$. ${ }^{*} p<0.05$ and ${ }^{* *} p<0.01$ (in comparison to the control); (C) Cleaved caspase-3 activity was measured following the treatment of LNCaP cells with LA $(0,50,100$ and $200 \mu \mathrm{M})$ for $48 \mathrm{~h} .{ }^{* *} p<0.01$ and ${ }^{* * *} p<0.001$ (in comparison to the control); (D) LNCaP cells were treated with LA $(0,50,100$ and $200 \mu \mathrm{M})$ for $48 \mathrm{~h}$ and subjected to Western blot analysis of apoptosis marker protein levels (Bcl-2, BAX, cleaved caspase-9, cleaved caspase-3, PARP).

\subsection{Lambertianic Acid Attenuates AR and PSA Expression in LNCaP Cells}

The effect of a non-apoptotic concentration of LA was tested on PSA and AR expression after treatment for 24 and $48 \mathrm{~h}$. As shown in Figure 3A, LA decreased the PSA and AR protein level following 24 and $48 \mathrm{~h}$ of exposure. Furthermore, LA decreased the secretion of PSA into the conditioned medium concentration and time dependently (Figure 3B). Incubation with $100 \mu \mathrm{M}$ LA for $24 \mathrm{~h}$ and $48 \mathrm{~h}$ led to a $51 \%$ and a $90 \%$ reduction, respectively. 
A.

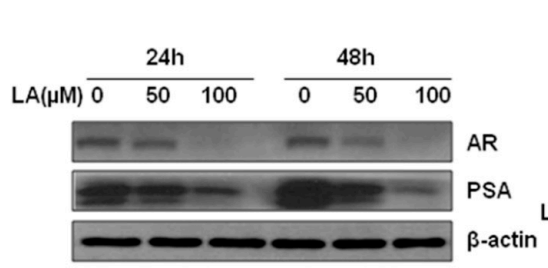

C.

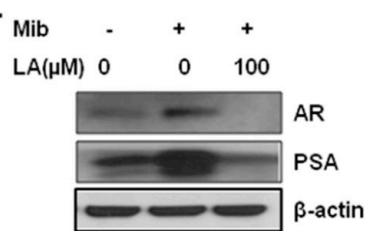

E.

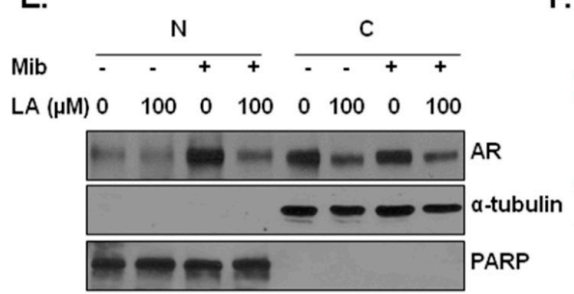

B.

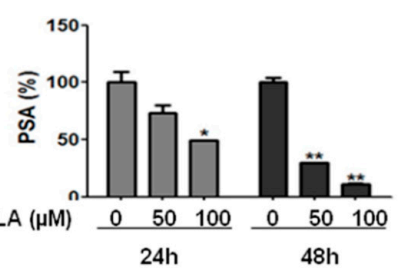

D.

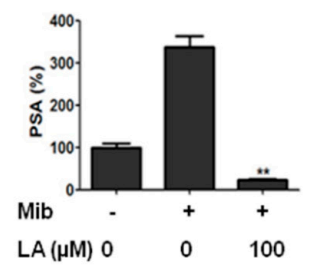

F.

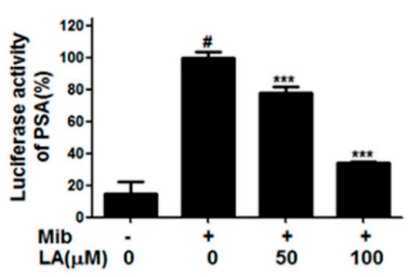

Figure 3. Concentration-dependent inhibition of PSA and AR and the time course of inhibition of PSA and AR by LA. (A) Western blot analysis of cellular prostate-specific antigen (PSA) and androgen receptor (AR) following the treatment of LNCaP cells with LA for 24 and $48 \mathrm{~h}$; (B) ELISA measurement of secreted PSA after $24 \mathrm{~h} .{ }^{*} p<0.05$ and ${ }^{* *} p<0.01$ (in comparison to the control); (C) LNCaP cells were seeded in phenol red-free medium supplemented with $5 \%$ charcoal-stripped serum. Western blot analyses of cellular PSA and AR following treatment with LA, with or without mibolerone (Mib); (D) LNCaP cells were seeded in phenol red-free medium supplemented with 5\% charcoal-stripped serum. ELISA of secreted PSA measured following treatment with LA, with or without Mib. ${ }^{* *} p<0.01$ (in comparison to the control); (E) LNCaP cells were seeded in phenol red-free medium supplemented with $5 \%$ charcoal-stripped serum in a T25 plate. Cells were treated with LA (0 and $100 \mu \mathrm{M})$ and Mib $(1 \mathrm{nM})$. LNCaP cells were harvested and then separated into nuclear and cytosolic fractions using the NE-PER Nuclear and Cytoplasmic Extraction Reagent kit (Thermo Scientific, Waltham, MA, USA), and then, the specificity of separation was confirmed using Western blotting for total poly-ADP-ribose polymerase (PARP) and $\alpha$-tubulin as respective nuclear and cytosolic markers; (F) LNCaP cells were seeded in phenol red-free medium supplemented with $5 \%$ charcoal-stripped serum in culture plates and then transfected with luciferase reporter plasmids combined with the PSA-Luc reporter for $24 \mathrm{~h}$. Cells were treated with LA (0,50 nd $100 \mu \mathrm{M})$ or mibolerone (Mib, $1 \mathrm{nM})$ and lysed, and then reporter activity was analyzed using the Luciferase Reporter Assay system (Promega, Madison, AL, USA). $\# p<0.05$ (in comparison to the untreated control) and ${ }^{* * *} p<0.001$ (in comparison to the Mib-treated control).

\subsection{Lambertianic Acid Inhibits Androgen-Stimulated AR Nuclear Translocation}

To determine whether LA affects the AR and PSA level of androgen-stimulated LNCaP cells, they were pretreated with LA $(0$ and $100 \mu \mathrm{M})$ for $1 \mathrm{~h}$ and then further stimulated with mibolerone (Mib, $1 \mathrm{nM}$ ) for $23 \mathrm{~h}$ in the presence of LA. As shown in Figure 3C, LA decreased the AR protein level, while Figure 3C,D shows that in the presence of Mib, LA effectively blocked the androgen-stimulated cellular and secreted PSA. 
To determine whether LA affects AR nuclear translocation, LNCaP cells were pretreated with LA $(0$ and $100 \mu \mathrm{M})$ for $1 \mathrm{~h}$ and then further stimulated with Mib $(1 \mathrm{nM})$ for $23 \mathrm{~h}$ in the presence of LA. As shown in Figure 3E, treatment with LA blocked the androgen-stimulated translocation of AR to the nucleus and decreased its protein expression. These results suggest that LA prevented AR from activating PSA mRNA transcription and protein expression. To verify the transcriptional inhibition induced by LA, the PSA promoter luciferase activity was evaluated by a transient transfection assay. LA treatment for $24 \mathrm{~h}$ inhibited the androgen-stimulated PSA promoter transcription concentration dependently (Figure 3F).

\subsection{AR Signaling Mediates Lambertianic Acid-Induced Cell Proliferation Suppression and Apoptosis}

This study showed that AR is a pivotal factor in prostate cancer development. The inhibitory effects of LA on AR were confirmed by transfecting AR siRNA into LNCaP cells. Silencing AR reduced its level, as well as that of PSA in the presence or absence of LA. Furthermore, AR knockdown inhibited $\mathrm{G}_{1}$ regulatory protein levels (cyclin D1 and CDK4) and increased the tumor suppressor genes (p53, p21 and p27) (Figure 4A). In addition, knockdown of the AR in LNCaP cells suppressed their proliferation by $30.1 \%$ compared to cells transfected with the CON siRNA (Figure 4B,C). Accordingly, these results demonstrated that inhibition of AR expression by AR siRNA suppressed the proliferation of LNCaP cells. To confirm apoptosis by silencing AR, cell cycle and cleaved caspase-3 activity analyses were performed. AR knockdown increased the sub- $\mathrm{G}_{1}$ phase and caspase-3 activity (Figure 5A,B). In addition, AR silencing increased apoptosis-related protein expression (BAX, cleaved caspase-9, cleaved caspase-3 and cleaved-PARP) and inhibited Bcl-2 (Figure 5B). These results suggest that AR plays an important role in LA-induced cancer-cell growth inhibition in AR-sensitive LNCaP cells.

A.

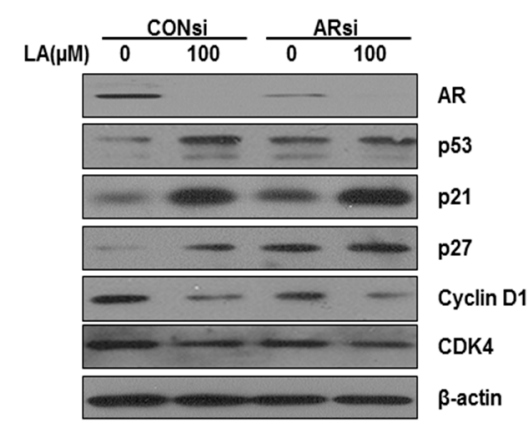

B.

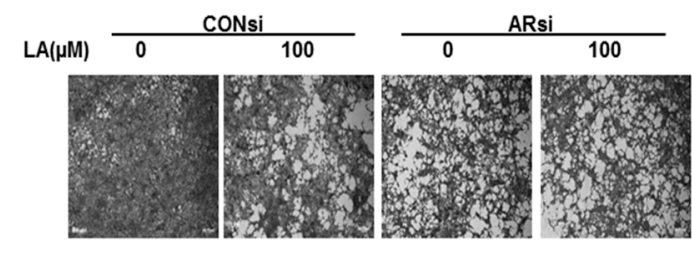

c.

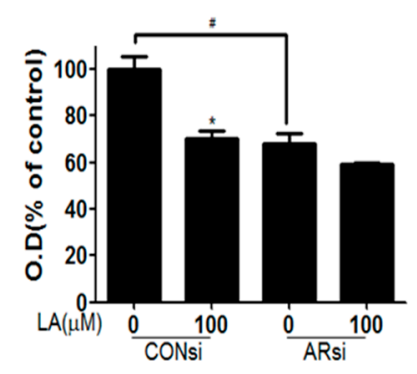

Figure 4. Effect of silencing androgen receptor (AR)-induced proliferation in LNCaP cells. (A) LNCaP cells were transfected with AR-siRNA for $24 \mathrm{~h}$, treated with LA $(0$ and $100 \mu \mathrm{M})$ for $24 \mathrm{~h}$ and then analyzed using Western blot; (B) Anti-proliferative activity following silencing of AR was evaluated using the cell growth assay. LNCaP cells were transfected with AR siRNA for $24 \mathrm{~h}$, treated with LA ( 0 and $100 \mu \mathrm{M})$, and incubated for three days; (C) Cells were stained; randomly chosen fields were photographed and resolved in $70 \%$ ethanol after washing with distilled water, and absorbance was read using a microplate reader $(590 \mathrm{~nm})$. $\# p<0.05$ and ${ }^{*} p<0.05$ (in comparison to the control). 
A.

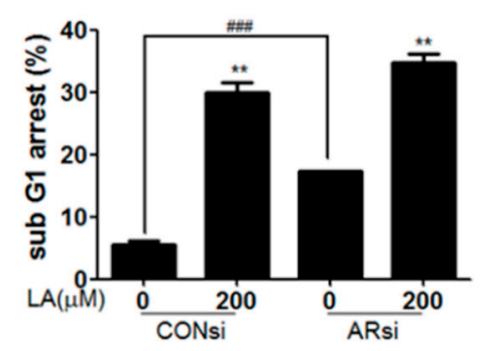

B.

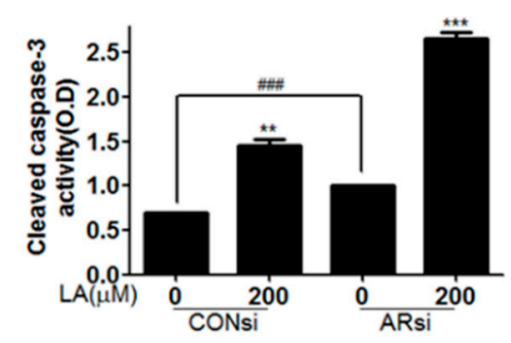

C.

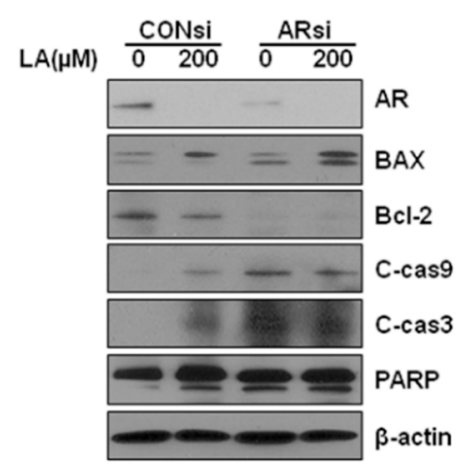

Figure 5. Effect of silencing androgen receptor (AR)-induced apoptosis of LNCaP cells. (A) Cell cycle analysis was measured following treatment with LA $(0$ and $200 \mu \mathrm{M})$ for $48 \mathrm{~h}$ after transfection with AR-siRNA for $24 \mathrm{~h}$ in LNCaP cells. \#\#\# $p<0.001$ and ${ }^{* *} p<0.01$ (in comparison to the control); (B) Cleaved caspase-3 activity also was measured with treated LA (0 and $200 \mu \mathrm{M})$ for $48 \mathrm{~h}$ after transfection with AR-siRNA for $24 \mathrm{~h}$ in LNCaP cells; (C) LNCaP cells were transfected with AR-siRNA for $24 \mathrm{~h}$, treated with LA $(0$ and $200 \mu \mathrm{M})$ for $48 \mathrm{~h}$ and then subjected to Western blot analysis of apoptosis-related protein expression. \#\#\# $p<0.001,{ }^{* *} p<0.01$ and ${ }^{* * *} p<0.001$ (in comparison to the control).

\section{Discussion}

Here, we demonstrated that LA blocked AR signaling (anti-androgenic) by impairing the nuclear translocation of the stimulated AR and decreasing its protein expression. LA is a bioactive diterpene, which exerts anti-allergic and antibacterial effects $[17,18]$. LA is found to naturally occur in Pinaceae or Cupressaceae family species $[20,21]$. We recently reported that LA, a bioactive constituent of P. koraiensis, has anti-obesity effects [22]. Nevertheless, the specific effect of LA on tumor proliferation and survival has not been examined previously. Our findings indicate that LA has anticancer effects in AR-dependent prostate cancer cells, as revealed by the determination of AR regulation. In this study, LA suppressed AR expression, as well as cellular and secretory levels of PSA in AR-sensitive cells. Androgen and the AR are crucial for prostate function and are involved in various stages of diseases [4].

PSA is a gene that is regulated by androgen in the normal prostate and prostate cancer cells [23]. PSA is a biomarker routinely used for the early detection of prostate cancer and in monitoring response to treatments [24]. The AR plays a pivotal role in prostate cancer development [6,7] and is related to cell cycle progression in the $G_{1} / S$ phase [25], as well as inhibition of apoptosis. Several studies have reported that natural compounds or herbal extracts inhibit cancer cell growth and induce apoptosis by downregulating AR signaling [26,27].

Inhibition of the AR suppresses cell cycle progression by inhibiting the function and activity of cyclins and CDKs in androgen-dependent prostate cancer cells [28]. Cyclin/CDK complexes are 
important regulators of the cell cycle and are involved in abnormal cancer cell growth [29]. Treatment of LNCaP cells with LA for $24 \mathrm{~h}$ increased the $\mathrm{G}_{1}$ phase by downregulating CDK and cyclin D1 (Figure 1F), while treatment for $48 \mathrm{~h}$ induced apoptosis (Figure 2D).

To verify the role of AR signaling in the anticancer effects of LA, its role in the anti-proliferation and apoptosis induced by LA was examined using AR siRNA transfection and Mib. Mib is a potent anabolic steroid and has a high affinity for the androgen receptor. Overexpression of AR with Mib induced cell proliferation-related proteins cyclinD1 and PCNA and inhibited apoptosis by inducing BCl-2 and cleaved PARP, while LA inhibited Mib-induced cell proliferation and induced apoptosis in LNCaP cells with Mib (Supplementary Figure S1). The deficiency of AR increased the $\mathrm{G}_{1}$ phase in the prostate cancer cells [25]. Liao et al. [30] reported that siRNA-induced AR silencing leads to apoptotic cell death in prostate cancer. Consistently, our data showed that AR siRNA transfection noticeably induced apoptosis by upregulating BAX, cleaved caspase-9, -3 and cleaved PARP and downregulating Bcl-2. Furthermore, our results showed that AR siRNA transfection decreased cell proliferation by downregulating CDK and cyclin D1, as well as upregulating p21 and p27. Knockdown of AR with siRNA enhanced the inhibitory effect of LA on LNCaP cell proliferation by inhibiting cyclin D1 and CDK4 and inducing p53, p21 and p27 (Figure 4). Further, AR knockdown enhanced LA-mediated apoptosis by inducing BAX and cleaved caspase-9, - 3 and PARP and inhibiting BCl-2, as well as inducing subG1 arrest and cleaved caspase-3 activity. Combined, these data suggest that LA suppresses cell proliferation and induces apoptosis via the inhibition of AR signaling in androgen-responsive prostate cancer cells.

LA affects more LNCaP cells than PC-3 and DU145 cells in Figure 1B. However, $200 \mu$ M LA has a cytotoxic effect on even castration-resistant cells, both PC-3 and DU145 cells. Furthermore, knockdown of AR using AR siRNA enhances the LA-induced apoptosis (Figure 5). These data suggest that LA has the potential to inhibit upstream proteins of AR, such as NF-kappaB [31], MAPKs (AKT/PKB, PKA, PKC) and STAT-3 [32] or other androgen receptor coregulators.

In summary, LA suppressed protein expression and nuclear translocation of AR in androgen-stimulated LNCaP cells. In addition, LA significantly reduced the secretory and cellular levels of PSA in a concentration-dependent manner. LA suppressed cell proliferation by inhibiting $\mathrm{G}_{1}$ arrest and induced apoptosis by inhibiting AR signaling. Moreover, silencing AR siRNA blocked the stimulation of cell proliferation and enhanced apoptosis. This study elucidated the anticancer mechanism of LA by demonstrating that this effect was mediated via inhibition of AR signaling in androgen-sensitive prostate cancer cells.

\section{Materials and Methods}

\subsection{Test Compound}

Lambertianic acid (purity: $\geqslant 97 \%$ as determined by HPLC) was kindly provided by Lee Min-Ho, college of the health industry, Eulji University (Seongnam City, Korea). The substance was analytically confirmed using NMR and GCMS by Eulji University.

\subsection{Cell Culture Assay}

LNCaP, PC-3 and DU145 cells were purchased from the Korea Cell Line Bank (Seoul, Korea) and maintained in RPMI1640 medium (10\% FBS, 2 mM L-glutamine, 10 mM HEPES, 1 mM sodium pyruvate, $45 \mathrm{~g} / \mathrm{L}$ glucose and penicillin/streptomycin) (WelGene, Daegu, Korea) in a cell incubator.

\subsection{Cell Viability Assay}

Cells (LNCaP, DU-145 and PC-3 cells, $1 \times 10$ cells/well) were treated with various concentrations $(0,3.125,6.25,12.5,25,50,100 \mu \mathrm{M}$ and $200 \mu \mathrm{M})$ of LA in 96-well plates (SPL Life Science, Gyeonggi-do, Korea). After $24 \mathrm{~h}, 50 \mu \mathrm{L}$ of MTT solution ( $1 \mathrm{mg} / \mathrm{mL}$, Sigma, St. Louis, MO, USA) were added. 
After $1 \mathrm{~h}$ of incubation, optical density was determined by the microplate reader (Tecan, Switzerland) at $570 \mathrm{~nm}$.

\subsection{Western Blot Analysis}

LNCaP cells $\left(5 \times 10^{5}\right.$ cells/well) were cultured with or without LA (50, $100 \mu \mathrm{M}$ and $\left.200 \mu \mathrm{M}\right)$, mibolerone (Mib, $1 \mathrm{nM}$ ) or both in 6-well plates. Cell were lysed in radioimmunoprecipitation assay (RIPA) buffer (50 mM Tris-HCL, pH 7.4, $150 \mathrm{mM}$ sodium chloride (NaCl), 1\% NP-40, 0.25\% deoxycholic acid-Na, 1 M EDTA, $1 \mathrm{mM}$ sodium orthovanadate $\left(\mathrm{Na}_{3} \mathrm{VO}_{4}\right), 1 \mathrm{mM}$ sodium fluoride $(\mathrm{NaF})$ and protease inhibitor cocktail). Protein samples were quantified by using a Bio-Rad DC protein assay kit II (Bio-Rad, Hercules, CA, USA), separated by electrophoresis on a $10 \%$ to $15 \%$ SDS-PAGE gel and electrotransferred onto a Bio Trace NT transfer membrane (Pall, Gelman Laboratory, Port Washington, NY, USA). After blocking ( $3 \%$ nonfat skim milk), the membrane probed with primary antibodies against AR (BD Biosciences), PSA (Dako), p53 (Santa Cruz Biotechnologies, Santa Cruz, CA, USA), p21 (Cell Signaling Technology), p27, cyclin D1, CDK4, CDK6, B-cell lymphoma 2 (Bcl-2), Bcl-2-associated X protein (BAX) (Santa Cruz Biotechnologies, Santa Cruz, CA, USA), cleaved caspase-3, cleaved caspase-9 (Cell Signaling Technology), poly-ADP-ribose polymerase (PARP, Santa Cruz Biotechnologies, Santa Cruz, CA, USA) and $\beta$-actin (Sigma-Aldrich) overnight and then exposed to HRP-conjugated secondary anti-mouse or rabbit antibodies. Protein expression was examined using the EZ-Western Lumi Pico (DOGEN).

\subsection{Crystal Violet Staining}

LNCaP cells $\left(1 \times 10^{5}\right.$ cell/well) were seeded in 6-well plates and treated with or without of LA (50, 100 and $200 \mu \mathrm{M}$ ) for 3 and 5 days. Then, the cells were washed with PBS and fixed with $1 \%$ glutaraldehyde in PBS at $25^{\circ} \mathrm{C}$ for $20 \mathrm{~min}$, then stained with $0.05 \%$ crystal violet solution. The cells were then resolved in $70 \%$ ethanol, and the OD was measured using an ELISA reader at $570 \mathrm{~nm}$.

\subsection{Cell Cycle Analysis}

Cells were fixed with $75 \%$ ethanol and resuspended in PBS with RNase $(1 \mathrm{mg} / \mathrm{mL})$ at $37^{\circ} \mathrm{C}$ for $1 \mathrm{~h}$ and stained with propidium iodide (PI). The stained cells were analyzed for DNA content by FACS Calibur containing Cell-Quest Software (Becton-Dickinson, Heidelberg, Germany).

\subsection{AR Gene Silencing}

LNCaP cells $\left(2 \times 10^{5}\right.$ cell/well $)$ were seeded onto a 6-well plate and transfected with $100 \mathrm{nM}$ of AR-specific control (CON) siRNA or siRNA (Bioneer, Daejeon, Korea) using INTERFER transfection reagent (Poly Plus, Illkirch, France) for 24 or $48 \mathrm{~h}$. Then, the cells were treated with or without of LA $(100 \mu \mathrm{M})$, and transfection was confirmed using Western blot analysis and a luciferase assay.

\subsection{Luciferase Assay}

LNCaP cells were transfected with luciferase reporter plasmids combined with a PSA-Luc reporter for $24 \mathrm{~h}$, treated with LA for $24 \mathrm{~h}$ and then lysed followed by analysis of the reporter activity using the Luciferase Reporter Assay system (Promega, Madison, AL, USA).

\subsection{Caspase-3 Activity}

Caspase activity was measured using the manufacturer's protocols (caspase- 3 colorimetric assay kits; R\&D Systems Inc., Minneapolis, MN, USA). Cells were lysed in lysis buffer. The cell lysates were treated with caspase-3-specific substrates at $37^{\circ} \mathrm{C}$ for $4 \mathrm{~h}$. Caspase-3 activity and absorbance were measured with a microplate reader at $430 \mathrm{~nm}$. 


\subsection{Statistical Analysis}

Data were shown as the means \pm standard deviation (SD) of three or more replicates, and the statistical significance was verified by Student's $t$-test.

Supplementary Materials: Supplementary materials can be found at http://www.mdpi.com/1422-0067/17/7/ $1066 / \mathrm{s} 1$.

Acknowledgments: This work was supported by grants (No. 2013R1A1A1008431 and No. PJ009055) from the National Research Foundation of Korea (NRF) (MSIP, Ministry of Science, ICP and Future Planning) and the Next-Generation Bio-green 21 program, Rural Development Administration funded by the Korea Government.

Author Contributions: Hyo-Jeong Lee conceived and designed the experiments; Myoun-Sun Lee and Seon-Ok Lee performed the experiments; Eun-Ok Lee analyzed the data; and Sung-Hoon Kim contributed reagents/analysis tools. All authors read and approved the final manuscript.

Conflicts of Interest: The authors declare no conflict of interest.

\section{Abbreviations}

LA lambertianic acid

AR androgen receptor

PBS phosphate-buffered saline

OD optical density

\section{References}

1. Ferlay, J.; Soerjomataram, I.; Dikshit, R.; Eser, S.; Mathers, C.; Rebelo, M.; Parkin, D.M.; Forman, D.; Bray, F. Cancer incidence and mortality worldwide: Sources, methods and major patterns in globocan. Int. J. Cancer 2012, 136, E359-E386. [CrossRef] [PubMed]

2. Siegel, R.; Ma, J.; Zou, Z.; Jemal, A. Cancer statistics. CA Cancer J. Clin. 2014, 64, 9-29. [CrossRef] [PubMed]

3. Bennett, N.C.; Gardiner, R.A.; Hooper, J.D.; Johnson, D.W.; Gobe, G.C. Molecular cell biology of androgen receptor signalling. Int. J. Biochem. Cell Biol. 2010, 42, 813-827. [CrossRef] [PubMed]

4. Andriole, G.; Bruchovsky, N.; Chung, L.W.; Matsumoto, A.M.; Rittmaster, R.; Roehrborn, C.; Russell, D.; Tindall, D. Dihydrotestosterone and the prostate: The scientific rationale for 5alpha-reductase inhibitors in the treatment of benign prostatic hyperplasia. J. Urol. 2004, 172, 1399-1403. [CrossRef] [PubMed]

5. Feitelson, M.A.; Arzumanyan, A.; Kulathinal, R.J.; Blain, S.W.; Holcombe, R.F.; Mahajna, J.; Marino, M.; Martinez-Chantar, M.L.; Nawroth, R.; Sanchez-Garcia, I.; et al. Sustained proliferation in cancer: Mechanisms and novel therapeutic targets. Semin. Cancer Biol. 2015, 35, S25-S54. [CrossRef] [PubMed]

6. Heinlein, C.A.; Chang, C. Androgen receptor in prostate cancer. Endocr. Rev. 2004, 25, 276-308. [CrossRef] [PubMed]

7. Taplin, M.E.; Balk, S.P. Androgen receptor: A key molecule in the progression of prostate cancer to hormone independence. J. Cell. Biochem. 2004, 91, 483-490. [CrossRef] [PubMed]

8. Cleutjens, K.B.; van der Korput, H.A.; van Eekelen, C.C.; van Rooij, H.C.; Faber, P.W.; Trapman, J. An androgen response element in a far upstream enhancer region is essential for high, androgen-regulated activity of the prostate-specific antigen promoter. Mol. Endocrinol. 1997, 11, 148-161. [CrossRef] [PubMed]

9. Cleutjens, K.B.; van Eekelen, C.C.; van der Korput, H.A.; Brinkmann, A.O.; Trapman, J. Two androgen response regions cooperate in steroid hormone regulated activity of the prostate-specific antigen promoter. J. Biol. Chem. 1996, 271, 6379-6388. [PubMed]

10. Riegman, P.H.; Vlietstra, R.J.; van der Korput, J.A.; Romijn, J.C.; Trapman, J. Characterization of the prostate-specific antigen gene: A novel human kallikrein-like gene. Biochem. Biophys. Res. Commun. 1989, 159, 95-102. [CrossRef]

11. Yu, H.M.; Wu, Y.; Ju, P.; Wang, B.H.; Yang, X.D.; Wang, H.M.; Xu, L.C. Enos-jnk1-ar signaling pathway mediates deltamethrin-induced germ cells apoptosis in testes of adult rats. Environ. Toxicol. Pharmacol. 2014, 38, 733-741. [CrossRef] [PubMed] 
12. Tong, K.L.; Chan, K.L.; AbuBakar, S.; Low, B.S.; Ma, H.Q.; Wong, P.F. The in vitro and in vivo anti-cancer activities of a standardized quassinoids composition from eurycoma longifolia on lncap human prostate cancer cells. PLoS ONE 2015, 10, e0121752. [CrossRef] [PubMed]

13. Wang, Y.; Liu, G.; Tong, D.; Parmar, H.; Hasenmayer, D.; Yuan, W.; Zhang, D.; Jiang, J. Metformin represses androgen-dependent and androgen-independent prostate cancers by targeting androgen receptor. Prostate 2015, 75, 1187-1196. [CrossRef] [PubMed]

14. Shenk, J.L.; Fisher, C.J.; Chen, S.Y.; Zhou, X.F.; Tillman, K.; Shemshedini, L. P53 represses androgen-induced transactivation of prostate-specific antigen by disrupting har amino- to carboxyl-terminal interaction. J. Biol. Chem. 2001, 276, 38472-38479. [CrossRef] [PubMed]

15. Won, S.H.; Lee, H.J.; Jeong, S.J.; Lu, J.; Kim, S.H. Activation of p53 signaling and inhibition of androgen receptor mediate tanshinone iia induced g1 arrest in lncap prostate cancer cells. Phytother. Res. 2012, 26, 669-674. [CrossRef] [PubMed]

16. Bruckheimer, E.M.; Spurgers, K.; Weigel, N.L.; Logothetis, C.; McDonnell, T.J. Regulation of bcl-2 expression by dihydrotestosterone in hormone sensitive lncap-fgc prostate cancer cells. J. Urol. 2003, 169, 1553-1557. [CrossRef] [PubMed]

17. Yang, X.; Zhang, Y.C.; Zhang, H.; Wang, J. Isolation and identification of diterpenoids from Pinus koraiensis. J. Chin. Med. Mater. 2008, 31, 53-55.

18. Chae, H.S.; Khiev, P.; Lee, H.K.; Oh, S.R.; Chin, Y.W. Anti-allergic effect of a chloroform-soluble extract of cinnamomum cambodianum in bone marrow-derived mast cells. Immunopharmacol. Immunotoxicol. 2012, 34, 639-644. [CrossRef] [PubMed]

19. Tolstikova, T.G.; Voevoda, T.V.; Dolgikh, M.P.; Sorokina, I.V. Neurotropic activity of lambertian acid and its amino derivatives. Eksp. Klin. Farmakol. 2002, 65, 9-11. [PubMed]

20. Yang, X.; Ding, Y.; Sun, Z.H.; Zhang, D.M. Studies on chemical constituents of pinus armandii. Acta Pharm. Sin. 2005, 40, 435-437.

21. Chae, H.S.; Chin, Y.W. Anti-allergic effect of Lambertianic acid from thuja orientalis in mouse bone marrow-derived mast cells. Immunopharmacol. Immunotoxicol. 2012, 34, 250-255. [CrossRef] [PubMed]

22. Lee, M.S.; Cho, S.M.; Lee, M.H.; Lee, E.O.; Kim, S.H.; Lee, H.J. Ethanol extract of Pinus koraiensis leaves containing Lambertianic acid exerts anti-obesity and hypolipidemic effects by activating adenosine monophosphate-activated protein kinase (ampk). BMC Complement. Altern. Med. 2016, 16, 51. [CrossRef] [PubMed]

23. Balk, S.P.; Ko, Y.J.; Bubley, G.J. Biology of prostate-specific antigen. J. Clin. Oncol. 2003, 21, $383-391$. [CrossRef] [PubMed]

24. Pezaro, C.; Woo, H.H.; Davis, I.D. Prostate cancer: Measuring psa. Intern. Med. J. 2014, 44, 433-440. [CrossRef] [PubMed]

25. Knudsen, K.E.; Arden, K.C.; Cavenee, W.K. Multiple g1 regulatory elements control the androgen-dependent proliferation of prostatic carcinoma cells. J. Biol. Chem. 1998, 273, 20213-20222. [CrossRef] [PubMed]

26. Wang, Z.; Lee, H.J.; Wang, L.; Jiang, C.; Baek, N.I.; Kim, S.H.; Lu, J. Anti-androgen receptor signaling and prostate cancer inhibitory effects of sucrose- and benzophenone-compounds. Pharm. Res. 2009, 26, 1140-1148. [CrossRef] [PubMed]

27. Guo, J.; Jiang, C.; Wang, Z.; Lee, H.J.; Hu, H.; Malewicz, B.; Lee, H.J.; Lee, J.H.; Baek, N.I.; Jeong, J.H.; et al. A novel class of pyranocoumarin anti-androgen receptor signaling compounds. Mol. Cancer Ther. 2007, 6, 907-917. [CrossRef] [PubMed]

28. Kokontis, J.M.; Lin, H.P.; Jiang, S.S.; Lin, C.Y.; Fukuchi, J.; Hiipakka, R.A.; Chung, C.J.; Chan, T.M.; Liao, S.; Chang, C.H.; et al. Androgen suppresses the proliferation of androgen receptor-positive castration-resistant prostate cancer cells via inhibition of cdk2, cyclina, and skp2. PLoS ONE 2014, 9, e109170. [CrossRef] [PubMed]

29. Lee, Y.M.; Sicinski, P. Targeting cyclins and cyclin-dependent kinases in cancer: Lessons from mice, hopes for therapeutic applications in human. Cell Cycle 2006, 5, 2110-2114. [CrossRef] [PubMed]

30. Liao, X.; Tang, S.; Thrasher, J.B.; Griebling, T.L.; Li, B. Small-interfering rna-induced androgen receptor silencing leads to apoptotic cell death in prostate cancer. Mol. Cancer Ther. 2005, 4, 505-515. [CrossRef] [PubMed] 
31. Zhang, L.; Altuwaijri, S.; Deng, F.; Chen, L.; Lal, P.; Bhanot, U.K.; Korets, R.; Wenske, S.; Lilja, H.G.; Chang, C.; et al. Nf-kappab regulates androgen receptor expression and prostate cancer growth. Am. J. Pathol. 2009, 175, 489-499. [CrossRef] [PubMed]

32. Pelekanou, V.; Notas, G.; Stathopoulos, E.N.; Castanas, E.; Kampa, M. Androgen receptors in early and castration resistant prostate cancer: Friend or foe? Hormones 2013, 12, 224-235. [CrossRef] [PubMed]

(C) 2016 by the authors; licensee MDPI, Basel, Switzerland. This article is an open access article distributed under the terms and conditions of the Creative Commons Attribution (CC-BY) license (http://creativecommons.org/licenses/by/4.0/). 